\title{
Pengaruh Variasi Komposisi BaM/PAni Matriks Cat Epoxy pada Pelapisan Single Layer dengan Metode Spray Coating untuk Aplikasi Material Penyerap Radar
}

\author{
Rifki Rachman Kholid, Widyastuti, dan Rindang Fajarin \\ Departemen Teknik Material dan Metalurgi, Fakultas Teknologi Industri, Institut Teknologi Sepuluh Nopember \\ (ITS) \\ e-mail:wiwid@mat-eng.its.ac.id
}

\begin{abstract}
Abstrak-Penyerapan gelombang mikro dapat dilakukan melalui rekayasa material, menggunakan material RAM (RadarAbsorbing Material) yang terdiri dari material resistif dan material magnetik untuk menyerap gelombang radar. Material magnetik yang digunakan adalah BaM (Barium Heksafferit). Sintesis material BaM menggunakan metode solid state. Material BaM di dopping dengan $\mathrm{Zn}^{2+}$ untuk meningkatkan nilai Magnetic Saturation (Ms) dari 58,97 emu/gr menjadi Ms 60,04 emu/gr dan menurunkan nilai koersivitas (Hc) dari 4743 Oe menjadi 833,17 Oe. PAni (Polianiline) merupakan material polimer konduktif yang digunakan pada penelitian ini. Material PAni didapatkan dengan proses polimerisasi oksidasi kimia. Penggunaan PAni dikarenakan memiliki stabilitas thermal dan konduktivitas listrik yang baik sebesar $1,579 \times 10^{-5} \mathrm{~S} / \mathrm{cm}$. Komposit BaM/PAni kemudian dicampurkan dengan cat epoxy dengan variasi persen berat $5,10,15$ wt $\%$. Kemudian dilapiskan pada material alumunium 2024 dengan metode spray coating dengan lapisan single layer. Untuk mengetahui nilai rugi refleksi dari material RAM yang telah dilapisi pada plat alumunium dilakukan pengujian VNA (Vector Network Analyzer) pada rentang frekuensi 8$12 \mathrm{GHz}$. Didapatkan nilai $R_{\mathrm{L}}$ maksimum sebesar -26,34 dB 9,33 GHz dengan ketebalan 59,1 micron pada komposisi BaM/PAni 15 wt\%. Dari hasil penyerapan dan nilai ketebalan yang didapatkan, komposisi komposit BaM/PAni 15 wt\% terhadap matriks cat epoxy sesuai untuk aplikasi RAM pada pesawat.
\end{abstract}

Kata Kunci-RAM, Radar Absorbing Material, Barium Heksaferrit, Polianilin, Matriks Cat Epoxy, Spray Coating, Vector Network Analyzer.

\section{PENDAHULUAN}

$\mathrm{M}$ ATERIALuntuk menyerap gelombang elektromagnetik dinamakan Radar Absorbing Material (RAM). RAM terbuat dari dua bahan utama yaitu marterial resistif dan atau material magnetik [1]. Bahan magnetik yang digunakan yaitu
Barium M-Heksaferrit (BaM). Material BaM ini digunakan karena memiliki magnetisitas tinggi, temperatur curie tinggi dan dapat menyerap gelombang radar [2]. Untuk penyerapan medan listrik digunakan Polianilin (PAni) karena memiliki stabilitas thermal dan konduktivitas listrik yang baik. Penyerapan gelombang mikro dapat dilihat berdasarkan nilai rugi refleksinya. Semakin besar nilai negatif rugi refleksinya, maka semakin besar daya serap material tersebut terhadap gelombang mikro [3].

Meshram, dkk melakukan pelapisan plat alumunium sebagai material penyerap radar dengan perbandingan komposit RAM dan cat epoxy 60\%: 40\% dengan pelapisan single layer dan two layer, menghasilkan rugi refleksi terkecil $6 \mathrm{~dB}$ [4]. Efhana, dkk mensintesis BaM dengan doping ion $\mathrm{Zn}^{2+}$ dengan metode kopresipitasi kemudian mencampurkan BaM dengan cat epoxy dengan perbandingan 1:1 dan menghasilkan nilai rugi refleksi $-16 \mathrm{~dB}$ pada $18 \mathrm{GHz}$ [5].

Perlu dilakukannya pengembangan penelitian material penyerap radar. Oleh karena itu dilakukan penelitian dengan variasi komposisi komposit RAM (BaM/PAni) dan matriks cat epoxy metode pelapisan menggunakan airspray dengan lapisan single layer dan two layer. Dalam penelitian ini diharapkan menghasilkan nilai rugi refleksi RAM yang tinggi dengan ketebalan coating yang tipis. Pada penelitian ini variasi yang digunakan antara material RAM dan cat epoxy yaitu $5,10,15$, wt $\%$.

\section{METODOLOGI PENELITIAN}

\section{A. Material}

Material yang digunakan dalam sintesis komposit RAM (BaM/PAni) antar lain: Barium karbonat $\left(\mathrm{BaCO}_{3}\right)$, Serbuk Besi (III) Oksida $\left(\mathrm{Fe}_{2} \mathrm{O}_{3}\right)$, Serbuk $\mathrm{Zn}$, Anilin $\left(\mathrm{C}_{6} \mathrm{H}_{7} \mathrm{NH}_{2}\right)$, Dodecylbenzene Sulfonit Acid $\left(\mathrm{C}_{18} \mathrm{H}_{30} \mathrm{O}_{3} \mathrm{~S}\right)$, Amonium Perokdisulfat $\left(\left(\mathrm{NH}_{4}\right)_{2} \mathrm{~S}_{2} \mathrm{O}_{8}\right)$, Aseton $\left(\mathrm{C}_{3} \mathrm{H}_{6} \mathrm{O}\right)$.

Material tambahan yang digunakan antara lain : Cat Epoxy Primer 37035A, Hardener 92140, Thiner 96184, Methyl Ethyl Ketone. $\left(\mathrm{C}_{4} \mathrm{H}_{8} \mathrm{O}\right)$. 


\section{B. Sintesis Material BaM,}

Sintesis komposit BaM/PAni diawali dengan mensintesis material $\mathrm{BaM}$ dengan metode solid state. Langkah yang dilakukan yaitu menimbang serbuk $\mathrm{Fe}_{2} \mathrm{O}_{3}, \mathrm{BaCO}_{3}$, dan $\mathrm{Zn}$ sesuai perhitungan stoikiometri. Kemudian mencampurkan bahan dengan alkohol dan bola baja dengan perbandingan 1:5/3:5. Dilakukan proses milling dengan temperatur ruang selama 2 jam dengan kecepatan $150 \mathrm{rpm}$. Hasil proses milling kemudian dikalsinasi pada temperatur $1200^{\circ} \mathrm{C}$, dan didapatkan serbuk BaM. Serbuk BaM yang didapatkan kemudian dikarakterisasi dengan pengujian XRD pert PANanalytical, SEM-EDX FEI 850, FTIR Nicolet iS10, dan VSM 250 Dexing Magnet untuk mengetahui sifat magnetik dari BaM.

\section{Sintesis Material PAni}

Sintesis Material PAni menggunakan metode polimerisasi, dengan melarutkan Anilin dan DBSA (Dodecylbenzene Sulfonit Acid) dengan aquades selama 15 menit. Kemudian melarutkan larutan APS (Amonium Perokdisulfat) dengan aquades. Kemudian melakukan proses polimerisasi dengan mentitrasi larutan anilin dan DBSA menggunakan larutan APS selama 8 jam pada temperatur $0^{\circ} \mathrm{C}$. Hasil polimerisasi kemudian disaring dengan kertas saring dan dicuci dengan larutan aseton dan aquades. Prekursor PAni dikeringkan pada temperatur kamar. Serbuk PAni yang didapatkan kemudian dikarakterisasi dengan pengujian SEM-EDX FEI 850, FTIR Nicolet iS10, dan Inductance Capasitance Resistance hioki 3532-50 untuk mengetahui konduktivitas listrik dari material PAni.

\section{Pembuatan Spesimen Material Penyerap Radar}

Pembuatan spesimen dimulai dengan menyiapkan plat Alumunium 2024 yang akan digunakan sebagai substrat. Alumunium 2024 yang akan dilapisi dengan komposit RAM dilakukan proses surface treatment menggunakan alodine 1200S. Kemudian menyapkan komposit RAM dengan mencampurkan material BaM dan PAni dengan perbandingan 1:2,5 menggunakan ultrasonic cleaner selama 3 jam. Selanjutnya mencampur komposit RAM dengan cat epoxy dengan variasi berat komposit RAM : $0 \mathrm{wt} \%, 5 \mathrm{wt} \%, 10 \mathrm{wt} \%$, dan 15 wt \%. Proses pelapisan pada plat Alumunium menggunakan spray gun, tekanan yang digunakan sebesar 7 bar dan jarak semprot $300 \mathrm{~mm}$. Hasil pelapisan dikeringkan pada temperatur $21^{\circ} \mathrm{C}$ selama $48 \mathrm{jam}$. Kemudian Spesimen yang telah jadi dilakukan pengujian mikroskopik untuk mengetahui persebaran butir komposit RAM dan pengujian VNA (Vector Network Analyzer) untuk mengetahui nilai rugi refleksi dari tiap variasi spesimen.

\section{ANALISA DATA DAN PEMBAHASAN}

\section{A. Karakterisasi Struktur Komposit RAM}

Pengujian XRD untuk material BaM dilakukan dengan rentang sudut $10^{\circ}-90^{\circ}$ menggunakan panjang gelombang $\mathrm{CuKa} 1.54 \AA$. Data XRD diolah menggunakan software match untuk mendapatkan grafik yang lebih halus dan disatukan dengan software origin antara material $\mathrm{BaM}$ yang di dopping
Zn 0,5 dengan BaM Non-dopping ditunjukan pada Gambar 1 .

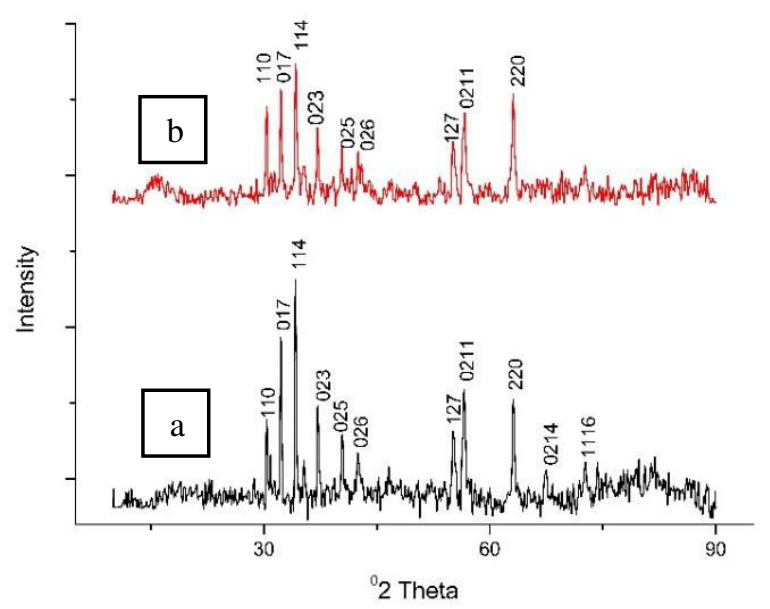

Gambar 1. Hasil Pengujian XRD Material BaM : a) BaM Non dopping b) BaM Dopping Zn.

Pada Gambar 1 terlihat bahwa kedua grafik menunjukan pola yang sama, dengan fase yang teridentifikasi adalah fase $\mathrm{BaFe}_{12} \mathrm{O}_{19}$. Material $\mathrm{BaM}$ Non Dopping terbentuk fasa tunggal $\mathrm{BaFe}_{12} \mathrm{O}_{19}$ dengan struktur kristal hexagonal JCPDS 96-1009034. Analisis kurva XRD dengan dopping ion $\mathrm{Zn}^{2+}$ juga menunjukan terbentuknya fase $\mathrm{BaFe}_{12} \mathrm{O}_{19}$ JCPDS 96-1009034. Terjadi pergeseran peak pada intesnsitas tertinggi dari $34.1620^{\circ}$ menjadi $34.1546^{\circ}$. Hal ini menandakan terjadinya substitusi ion $\mathrm{Zn}^{2+}$ yang mengganggu struktur kristal dari material BaM [6].

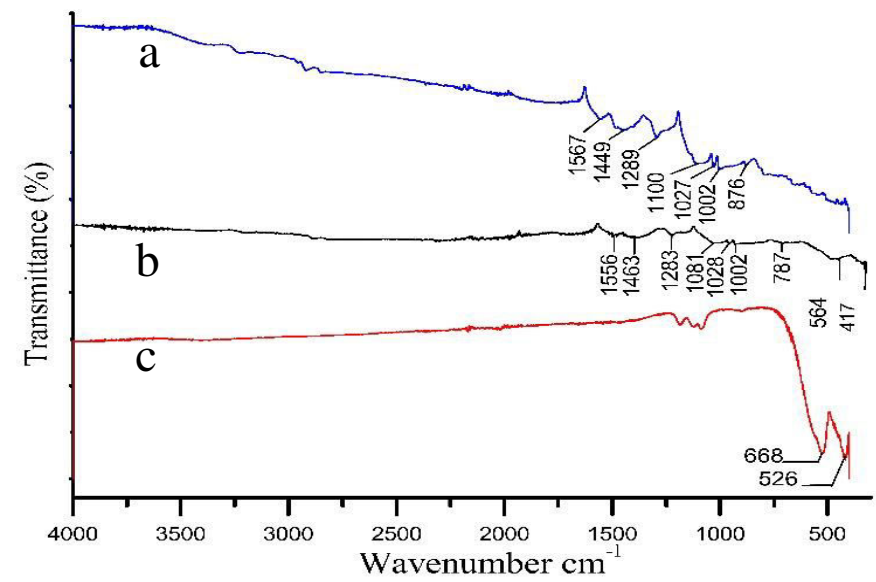

Gambar 2. Hasil Pengujian FTIR : a) Polianiline b) Komposit RAM c) BaM.

FTIR material RAM untuk mengetahui ikatan komposit $\mathrm{BaM} / \mathrm{PAni}$ telah terbentuk ditunjukan pada Gambar 2. Pada wavenumbers $1556 \mathrm{~cm}^{-1}$ terdapat $\mathrm{C}=\mathrm{C}$ quinoid. $\mathrm{C}=\mathrm{C}$ benzene terbentuk di nilai $1436 \mathrm{~cm}^{-1}$ [7]. Ikatan C-N terdapat pada peak $1283 \mathrm{~cm}^{-1}$ [8]. Pada komposit BaM/PAni terdapat juga ikatan $\mathrm{S}=\mathrm{O}$ yang menandakan doppan DBSA pada polianilin berhasil dilakukan dan membentuk ikatan dengan material BaM pada bilangan gelombang $1081 \mathrm{~cm}^{-1}$. Pada bilangan gelombang $1028 \mathrm{~cm}^{-1}$ menunjukan vibrasi ikatan $\mathrm{N}=\mathrm{Q}=\mathrm{N}$ pada $\mathrm{PAni}$ yang terdopping [9]. Terdapat ikatan M-O pada nilai 564 dan 417 
$\mathrm{cm}^{-1}$ yang menunjukan ikatan antar logam yang disebabkan oleh material $\mathrm{BaM}$ dengan Material Polianiline yang ditunjukan oleh gambar 4.13. Ikatan M-O terbentuk pada rentang $600-300 \mathrm{~cm}^{-1}$ [10]. Dari hasil FTIR yang didapat dapat disimpulkan bahwa material komposit BaM/PAni berhasil terbentuk

\section{B. Karakterisasi Morfologi dan EDX Komposit RAM}

Pada pengujian secara morfologi material BaM menggunakan uji SEM seperti terlihat pada Gambar 3 menunjukan bahwa material $\mathrm{BaM}$ yang tidak didopping dan didopping memiliki morfologi heksagonal. Pada material yang didopping denggan $\mathrm{Zn}$ memiliki morfologi heksagonal namun terdapat juga morfologi seperti agregat dikarenakan adanya interaksi antar partikel magneto dipol [9].
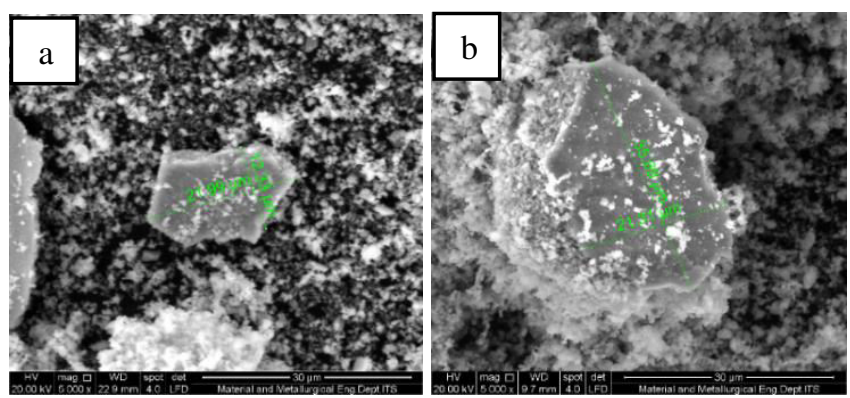

Gambar 3. Hasil Pengujian SEM Material BaM: a) Barium Non Dopping Perbesaran 5000x b) Barium Dopping Perbesaran 5000x

Ukuran partikel barium yang didopping memiliki nilai yang lebih besar yaitu $35,69 \mu \times 21,31 \mu$ sedangkan material yang tanpa dopping memiliki ukuran butir $21,99 \mu \times 12,33 \mu$. Ukuran partikel yang berbeda disebabkan karena dopping ion Zn yang memiliki nilai jari-jari atom lebih besar dari ion $\mathrm{Fe}^{2+}$, yaitu dengan nilai jari $\mathrm{Fe}$ sebesar $(0,645 \AA)$ dan $\mathrm{Zn}$ sebesar $(0,74 \AA)$ [11].

Dari analisis EDX ditunjukan pada Gambar 4 dilakukan untuk mengetahui komposisi element yang terdapat pada material $\mathrm{BaM}$. Jika dibandingkan dari kedua hasil EDX yang didapatkan bahwa terjadi pengurangan unsur $\mathrm{Fe}$ dari 70,11\% menjadi $68,02 \%$. Pada material yang didopping didapatkan unsur $\mathrm{Zn}$ pada material $\mathrm{BaM}$ yang didopping sebesar 4,47 wt $\%$, hal ini menunjukan bahwa pendoppingan unsur $\mathrm{Zn}$ berhasil dilakukan.

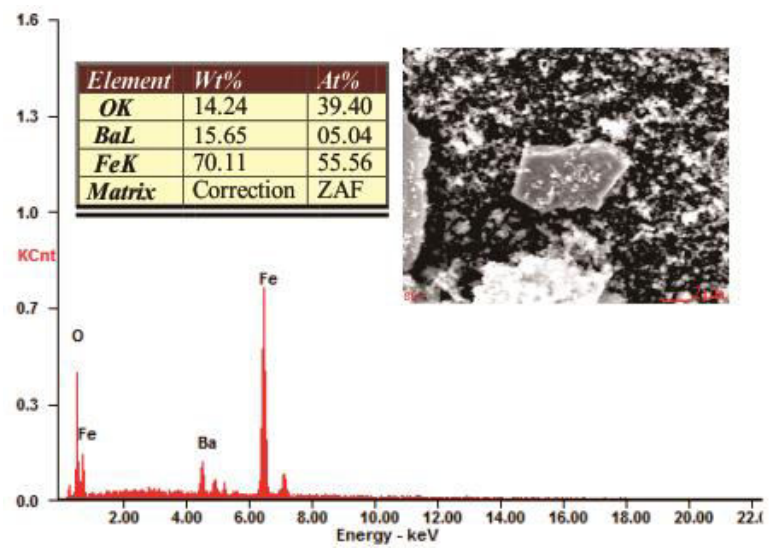

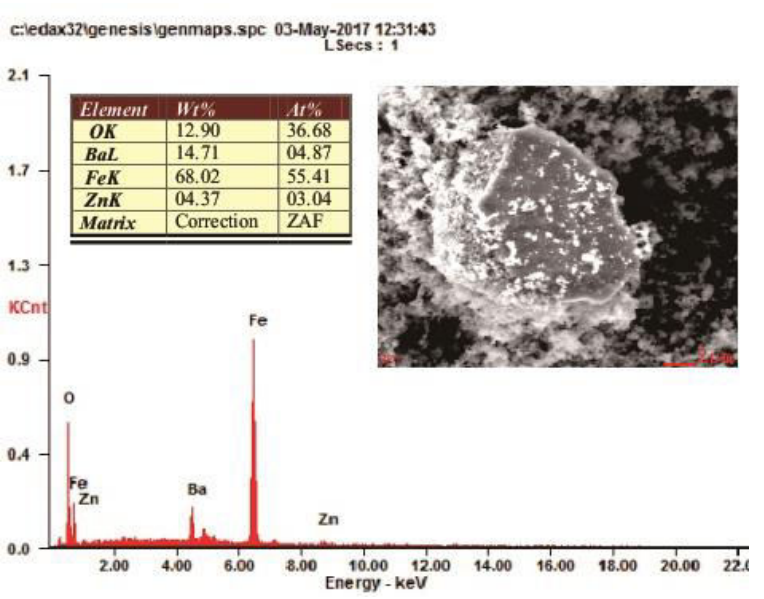

Gambar 4. Hasil Pengujian EDX ; a) Barium Non Dopping Perbesaran 2000x b) Barium Dopping Perbesaran 5000x

Pada Gambar 5.a terlihat partikel polianiline memiliki bentuk morfologi aglomerasi globular dan memiliki jarak antar molekul yang rapat. Pada perbesaran 5000x yang terdapat pada Gambar 5.b. terlihat lebih jelas agglomerasi atau penggumpalan dari serbuk polianilin yang dihasilkan. Penggumpalan pada serbuk polianiline disebabkan adanya sisa pelarut dalam proses polimerisasi. Penggumpalan yang terjadi dalam material polianiline mempengaruhi konduktivitas listrik yang dihasilkan menjadi lebih rendah [7].
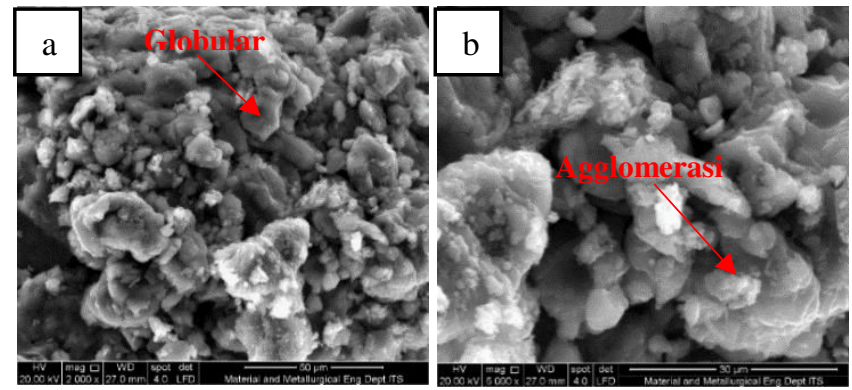

Gambar 5. Hasil SEM Material Polianilin ; a) Perbesaran 2000x b) Perbesaran $5000 x$

Distribusi komposisi partikel komposit BaM/PAni dianalisis menggunakan pengujian EDX ditampilkan pada Gambar 6, dari pengujian EDX didapatkan unsur penyusun PAni yaitu C,N,O,dan S [6]. Kemudian terdapat juga komposisi $\mathrm{Ba}, \mathrm{Fe}, \mathrm{O}$, dan $\mathrm{Zn}$ sebagai unsur penyusun material BaM. Dari hasil EDX yang dihasilkan membuktikan bahwa komposit RAM telah terbentuk dengan lebih banyak komposisi dari PAni, berat yang dihasilkan oleh komponen PAni lebih dominan. Hasil EDX sesuai dengan komposisi PAni dan BaM yang digunakan yaitu 2,5:1 perbandingan berat komposit.

\section{Sifat Kemagnetan}

Dari Gambar 7 dapat diketahui nilai saturasi magnetik (Ms) dan nilai koersivitas $(\mathrm{Hc})$ dari material $\mathrm{BaM}$ yang didopping dan tidak didopping. Nilai Magnetisasi BaM yang tidak didopping sebesar 58,97 emu/gr dan nilai koersivitas sebesar 
4743 Oe, sedangkan untuk material yang didopping memiliki Ms 60,04 emu/gr dan Hc 833,17 Oe.

Ukuran partikel yang berbeda dari hasil SEM Gambar 3 menyebabkan karakteristik magnet dari BaM memiliki nilai yang [12]. Substitusi ion $\mathrm{Zn}$ membuat arah dipol menjadi random sehingga material $\mathrm{BaM}$ yang didopping memiliki nilai magnetisasi saturasinya lebih besar karena semakin banyak energi yang dibutuhkan untuk mencapai arah dipol yang seorientasi dengan medan $\mathrm{H}$ [13]. Jika dibandingkan dengan material $\mathrm{BaM}$ yang dopping dengan ion $\mathrm{Zn}$ terjadi penurunan nilai koersivitas yang menjadikan material $\mathrm{BaM}$ dengan dopping Zn lebih bersifat softmagnetic. Rendahnya nilai koersivitas dan tingginya nilai saturasi magnetik membuat sifat absorbsinya menjadi semakin kuat [14]. Sifat ini sangat dibutuhkan untuk aplikasi material penyerap radar.

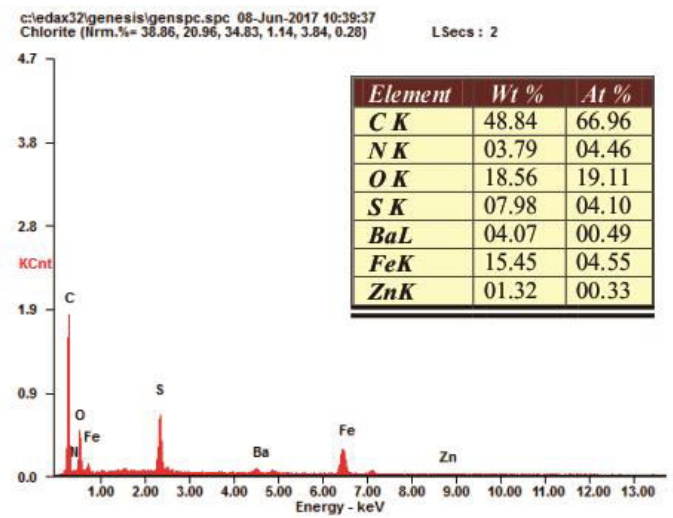

Gambar 6. Hasil Pengujian EDX Komposit BaM/PAni.

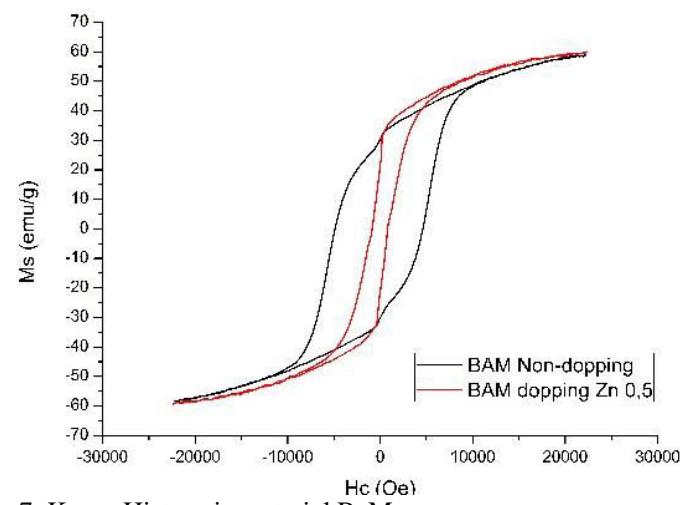

Gambar 7. Kurva Histeresis material BaM.

\section{Sifat Kelistrikan}

Dari hasil pengujian LCR meter pada Gambar 8 didapatkan nilai konduktivitas minimum sebesar 9,7 x $10^{-6}$ $\mathrm{S} / \mathrm{cm}$ dan nilai maksimum pada $1,579 \times 10^{-5} \mathrm{~S} / \mathrm{cm}$. Pada rentang tersebut material polianilin yang dihasilkan termasuk dalam kategori material semikonduktor. Seperti yang disebutkan oleh MacrDiamird (2001) bahwa material semikonduktor memiliki rentang $10^{2}$ sampai $10^{-7} \mathrm{~S} / \mathrm{cm}$, material konduktor lebih kecil dari $10^{-7} \mathrm{~S} / \mathrm{cm}$. Proses dopping pembentukan PAni dalam percobaan ini mengekspos polimer yang berupa isolator dengan agen transfer (DBSA) dalam fasa larutan melalui oksidasi kimia. Dengan proses ini menyebabkan PAni yang dihasilkan memiliki kemampuan menghantarkan listrik yang lebih tinggi karena peningkatan konsentrasi pembawa muatan didalam polimer [15].

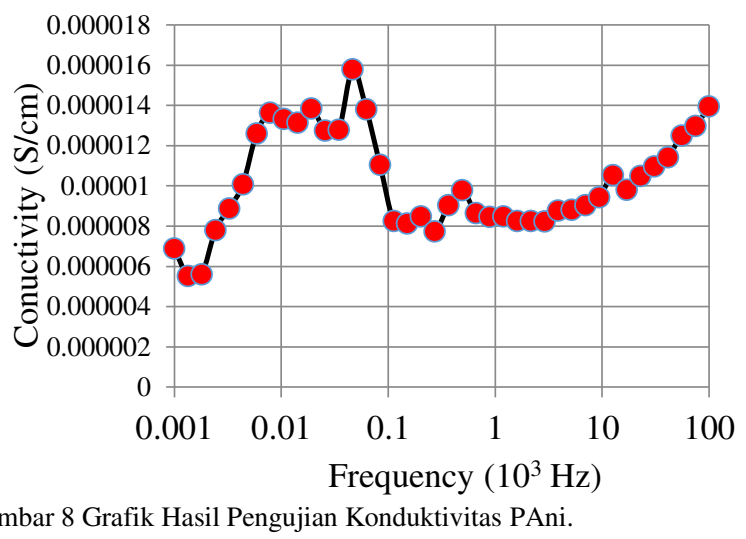

Nilai konduktivitas PAni yang tidak di dopping rendah yaitu sebesar $8,798 \times 10^{-8} \mathrm{~S} / \mathrm{cm}$. Pada proses dopping, protonproton ditambahkan ke situs- situs imina $(-\mathrm{N}=)$ sehingga terdapatnya vibrasi ikatan imina berpengaruh terhadap nila konduktivitas PAni [16]. Kemudian dopping dengan DBSA akan meningkatkan muatan PAni akibat delokalisasi muatan yang meningkat karena terbentuknya struktur polaron/bipolaron [17].

\section{E. Pengujian Mikroskopik}

Untuk mengetahui lebih jelas persebaran komposit RAM pada lapisan coating dilakukan pengujian makroskopik menggunakan stereomicroscope dengan menggunakan perbesaran $8 \mathrm{x}$. Hasil pengamatan pengujian ini ditampilkan pada Gambar 9.

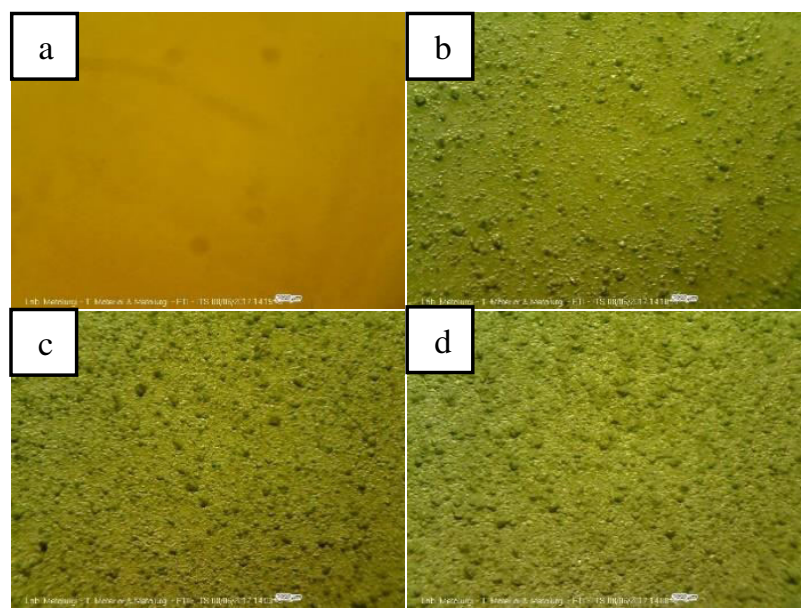

Gambar 9. Hasil Pengamatan Mikroskopik dengan Perbesaran 8x: : a) 0\%S b) $5 \% \mathrm{~S}$ c) $10 \% \mathrm{~S}$ d) $15 \% \mathrm{~S}$.

Spesimen tanpa dopping single layer Gambar 9.a mempunyai warna kuning keemasan, dikarenakan lapisan cat epoxy mempunyai ketebalan yang lebih tipis sehingga ketika dilakukan pengamatan terlihat juga warna dari plat alumunium hasil alodining. Penambahan komposisi komposit RAM 
menyebabkan meningkatnya jumlah partikel pada spesimen. Pada Gambar 9.d terdapat jumlah partikel komposir RAM yang paling banyak dikarenakan memiliki persentase penambahan yang paling besar. Banyaknya jumlah partikel komposit RAM meningkatkan nilai penyerapan gelombang elektromagnetik.

\section{F. Pengujian Vector Network Analyzer}

Pengukuran penyerapan gelombang elektromagnetik di lakukan dengan rentang $8-12 \mathrm{GHz}$ yang merupakan operasi gelombang mikro untuk teknologi militer. Pada pengujian ini menggunakan parameter S11 yang merupakan parameter absorbsi pada material dengan perantara adapter. Gambar 10 merupakan hasil pengujian VNA dari pelapisan single layer Hasil pengujian VNA setiap spesimen dengan nilai rugi refleksi maksimum ditampilkan pada Tabel 1 .

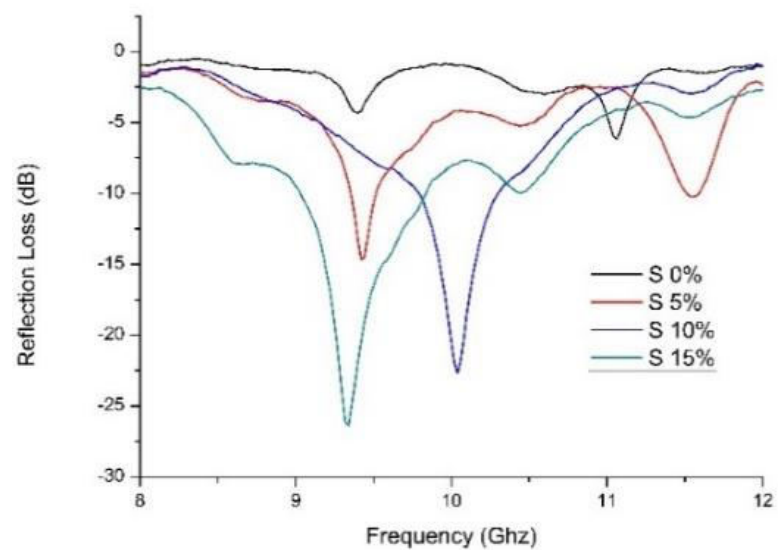

Gambar 10. Hasil Pengujian VNA.

Tabel 1.

Nilai Rugi Refleksi Maksimum Spesimen RAM

\begin{tabular}{|c|c|c|c|}
\hline Spesimen & $\begin{array}{l}\begin{array}{l}\text { Ketebalan } \\
\text { (micron) }\end{array}\end{array}$ & $\begin{array}{ll}\text { Rugi } & \text { Refleksi } \\
\text { (dB) } & \end{array}$ & $\begin{array}{l}\text { Frekuensi } \\
(\mathrm{GHz})\end{array}$ \\
\hline $0 \%$ single layer & 20,9 & $-5,872$ & 11,075 \\
\hline $5 \%$ single layer & 29 & $-14,659$ & 9,422 \\
\hline $10 \%$ single layer & 44,1 & $-22,441$ & 10,032 \\
\hline $15 \%$ single layer & 59,1 & $-26,344$ & 9,337 \\
\hline
\end{tabular}

Ketebalan lapisan juga merupakan salah satu faktor penting yang mempengaruhi sifat penyerapan, bahwa semakin meningkat ketebalan maka partikel penyerapan dan luas penyerapan didalam lapisan juga akan bertambah sehingga nilai absorbsi akan meningkat [18]. Dari Tabel 1 diketahui penambahan persen berat komposit RAM meningkatkan ketebalan dan nilai rugi refleksi. Penyerapan maksimum didapatkan dari spesimen penambahan $15 \mathrm{wt} \%$ komposit RAM sebesar -26,334 dB . Hal ini sesuai dengan hasil pengamatan dengan mikroskop optik, bahwa semakin banyak partikel komposit RAM dengan persebaran partikel yang merata maka proses penyerapan akan semakin meningkat. Perbedaan nilai rugi refleksi dari setiap spesimen berbeda beda berdasarkan dengan penambahan serbuk komposit RAM yang menyebabkan bertambahnya nilai ketebalan lapisan. Saat penambahan komposit RAM meningkat maka partikel-partikel menjadi semakin rapat dan luas penyerapan bertambah seperti yang terlihat pada Gambar 9, dan menyebabkan penyerapan gelombang elektromagnetik menjadi semakin tinggi.

\section{KESIMPULAN}

Penambahan komposisi komposit RAM meningkatkan nilai absorbsi gelombang elektromagnetik. Hal ini dikarenakan semakin tinggi komposisi komposit RAM maka semakin meningkat jumlah partikel komposit RAM dan mempengaruhi nilai rugi refleksi. Didapatkan nilai rugi refleksi pada variasi komposisi komposit RAM 0, 5, 10, dan 15 wt\% dengan pelapisan single layer, senilai : $-5,872 \mathrm{~dB},-14,659 \mathrm{~dB}$, $-22,441 \mathrm{~dB}$, dan $-26,344 \mathrm{~dB}$.

\section{DAFTAR PUSTAKA}

[1] P. Saville, "Review of Radar Absorbing Materials," Atlantic, 2005.

[2] L. Li, K. Chen, G. Liu, H. Tong, H. Qian, and B. Hao, "Attractive Microwave-Absorbing Properties of M-BaFe12O19 Ferrite," $J$. Alloys Compd., vol. 557, pp. 11-17, 2013.

[3] K. Y. Park, C.-G. Lee, S-E. Kim, and J.-H. Han, "Fabrication and Electromagnetic Characteristics of Electromagnetic Wave Absorbing Sandwich Structures," Compos. Sci. Technol., vol. 66, pp. 576-584, 2006.

[4] M. R. Meshram, K. A. Nawal, S. Bharoti, and P. S. Misra, “A Study on the behavior of M-type barium hexagonal ferrite based microwave absorbing paints," Bull Master. Sci., vol. 25, pp. 169173, 2002.

[5] E. D. Putri, E. S. A. Devi, V. Dita, S. A., and M. Zainuri, "Pembuatan Pelapisan Penyerapan Gelombang Mikro Berbasis MHexaferrite BaFe12-2xZnxO19 dari Pasir Alam Pada Kabin Pesawat," J. Fis. FMIPA, 2012.

[6] N. Sasria and Widyastuti, "Pengaruh Metode Pelapisan dan Ketebalan Lapisan terhadap Rugi Refleksi pada Barium MHeksaferrit/Poly(aniline,pyrrole, ethylene terephthalate) sebagai Material Penyerap Radar,' Institut Teknologi Sepuluh Nopember, 2016.

[7] J. Jiang and L. Ai, L-H. Lin-Y, "Poly(aniline-co-otoluidine)/BaFe12O19 Composite: Preparation and Characterization," Mater. Lett., vol. 64, pp. 888-890, 2010.

[8] B. D. Mistry, A Handbook of Spectroscopic Data Chemistry. Jaipur: Oxford Book Company, 2009.

[9] A. G. MacDiarmid, "Nobel Lecture: Synthetic Metals: a Novel Role for Organic Polymers," Rev. Mod. Phys., vol. 73, pp. 701-712, 2001.

[10] G. Socrates, Infrared and Raman Characteristic Group Frequencies, 3rd ed. London: John Wiley \& Sons, 2001.

[11] R. Agustianto, F. R. M. Dwi, R. D. Kristiputra, A. A. Marsha, and Widyastuti, "Magnetic Properties of Ni-Zn Doped M-Tipe Barium Hexaferrite Prepared by Sol-Gel Method," in Proceeding Basic Science International Conference, 2015, pp. 8-11.

[12] S. Kanagesan, M. Hashim, S. Jesurani, T. Kalaivani, and I. Ismail, Influence of $\mathrm{Zn}-\mathrm{Nb}$ on the Magnetic Properties of Barium Hexaferrite. Springer, 2013.

[13] E. L. . Nasution and Astuti, "Sintesis Nanokomposit PAni/Fe3O4 sebagai Penyerap Magnetik pada Gelombang Mikro,” J. Fis. Unand, vol. 1, no. 1, pp. 37-44, 2012.

[14] L. Silvia, "Pelapisan Komposit PAni/BaM-SiO2 Berbasis Material Alam sebagai Penyerap Gelombang Mikro dan Pelapis Anti Korosi pada Baja Grade A Tipe AH-36," Surabaya, 2013.

[15] N. A. K. Umiati, K. Triyanta, and K. Abraha, "Studi Pengaruh Konsentrasi Dopan pada Polianilin Nanofiber: Sintesis dan Karakterisasi Spektroskopi Infra-Red," in Seminar Nasional 2nd Lontar Physics Forum, 2013, pp. 1-5.

[16] J. Fernando and C. Vedhi, "Synthesis, Spectral and Electrochemical Characterization of Adipic Acid Doped Polyanilie," internatinal J. Sci. Technoledge, pp. 166-173, 2015.

[17] Z. Wang, H. Bi, J. Liu, T. Sun, and X. Wu, "Magnetic and Microwave Absorbing Properties of Polyaniline/ -Fe2O3 Nanocomposite," J. Magn. Magn. Mater., vol. 320, pp. 2132-2139, 2008. 
[18] H. Kaur and G. D. Aul, "A Review Based on Effects of Change in Thickness and Number of Layers on Microwave Absorbing Materials,” Int. J. Sci. Res., vol. 3, pp. 1141-1145, 2014. 